\title{
Vertebrate TFPI-2 C-terminal peptides exert therapeutic applications against Gram- negative infections
}

\author{
Gopinath Kasetty ${ }^{1}$, Emanuel Smeds², Emelie Holmberg², Louise Wrange ${ }^{2}$, Selvi Adikesavan ${ }^{3,4}$ \\ and Praveen Papareddy ${ }^{2 *}$ (D)
}

\begin{abstract}
Background: Tissue factor pathway inhibitor-2 (TFPI-2) is a serine protease inhibitor that exerts multiple physiological and patho-physiological activities involving the modulation of coagulation, angiogenesis, tumor invasion, and apoptosis. In previous studies we reported a novel role of human TFPI-2 in innate immunity by serving as a precursor for host defense peptides. Here we employed a number of TFPI-2 derived peptides from different vertebrate species and found that their antibacterial activity is evolutionary conserved although the amino acid sequence is not well conserved. We further studied the theraputic potential of one selected TFPI-2 derived peptide (mouse) in a murine sepsis model.
\end{abstract}

Results: Hydrophobicity and net charge of many peptides play a important role in their host defence to invading bacterial pathogens. In vertebrates, the C-terminal portion of TFPI-2 consists of a highly conserved cluster of positively charged amino acids which may point to an antimicrobial activity. Thus a number of selected C-terminal TFPI-2 derived peptides from different species were synthesized and it was found that all of them exert antimicrobial activity against $E$. coli and P. aeruginosa. The peptide-mediated killing of E. coli was enhanced in human plasma, suggesting an involvement of the classical pathway of the complement. Under in vitro conditions the peptides displayed anti-coagulant activity by modulating the intrinsic pathway of coagulation and in vivo treatment with the mouse derived VKG24 peptide protects mice from an otherwise lethal LPS shock model.

Conclusions: Our results suggest that the evolutionary conserved C-terminal part of TFPI-2 is an interesting agent for the development of novel antimicrobial therapies.

Keywords: TFPI-2, Peptide, Complement, Vertebrates, Antimicrobial, Coagulation, Sepsis, Evolution

\section{Background}

In response to pathogenic microorganisms, host organisms have evolved a diverse range of defense mechanisms, starting from simple mechanical barriers to complex immune systems. In these processes, blood coagulation, complement cascades and antimicrobial peptides are central to host defense and many components of these systems are evolutionary conserved [1]. The crosstalk between the coagulation and complement systems is essential for the clearance of the infection. Together they have a

\footnotetext{
* Correspondence: praveen.papareddy@med.lu.se

2Division of Infection Medicine, Department of Clinical Sciences, Lund

University, Biomedical Center, B14, Tornavägen 10, SE-221 84 Lund, Sweden Full list of author information is available at the end of the article
}

dual role of immobilization and destruction of invading bacteria in addition to preventing the loss of body fluids. Coagulation factors, apart from their primary role of maintaining hemostasis, are also involved in killing of bacteria and immunomodulation, such as thrombin [2], kininogen [3], protein $C$ inhibitor [4], fibrinogen [5, 6], antithrombin [7], TFPI-1 [8], and TFPI-2 [9, 10]. These proteins may explore their activities either as intact molecules or after proteolysis. Often they execute their host defense functions by killing the intruder or by triggering immunomodulatory reactions. Many well-characterized antimicrobial peptides have recently been found to exhibit also multifaceted immunomodulatory activities, such as reported for LL-37 [11, 12] and some antimicrobial peptides 
have been described to be involved in angiogenesis, chemotaxis, and wound-healing [11]. These biological properties suggest that host defense peptides may have a clinical potential also in disorders where targeting of inflammatory pathways is beneficial, such as in sepsis $[11,13]$.

Tissue factor pathway inhibitor 2 (TFPI-2) consists of a highly negatively charged $\mathrm{N}$-terminal region, three tandemly linked Kunitz-type domains, and a highly positively charged C-terminus [14, 15]. The molecule is synthesized and secreted by many cells, including skin fibroblasts, endothelial cells (ECs), smooth muscle cells (SMCs), dermal fibroblasts, keratinocytes, monocytes, macrophages and syncytiotrophoblasts $[16,17]$. In vitro, TFPI-2 is a weak inhibitor of coagulation induced by the TF-VII complex, while it targets a wide range of proteases such as trypsin, chymotrypsin, plasmin, MMPs, factor XIa and plasma kallikrein $[18,19]$. Stimulation of human umbilical vein endothelial cells with inflammatory mediators such as PMA, LPS, or TNF- $\alpha$ significantly increases TFPI2 expression [17]. Analogously, in a murine model, TFPI-2 expression is dramatically upregulated in the liver upon LPS stimulation [20]. Notably, it has been shown that proteases such as ADAMTS1, plasmin and thrombin can process TFPI- 2 at its C-terminal end in in vitro experiments [21]. We previously reported an undisclosed host defense function of the C-terminal region of TFPI-2 $[9,10]$. TFPI- 2 as well as the $\mathrm{C}$-terminal peptides of the molecule were detected in wounds from patients and were found in complex with the bacteria and fibrin. Correspondingly, human TFPI-2 was degraded in vitro by human neutrophil elastase, leading to the generation of $\mathrm{C}$ terminal TFPI- 2 fragments. These fragments were then found to bind to various bacterial surfaces, kill gramnegative bacteria, through membrane lysis, and boost complement activation, including formation of the membrane attack complex (MAC) and antimicrobial C3a. In a therapeutic context, the peptide significantly reduced mortality either as a monotherapy, or in combination with ceftazidime $E$. coli and $P$. aeruginosa sepsis models. We therefore hypothesized that TFPI-2 C-terminal derived peptides may have an important function in the host defense to infection, thus they may be interesting agents for drug development.

\section{Results}

\section{Phylogenetic and sequence analysis of the TFPI-2} C-terminal part from different species

A phylogenetic tree was constructed with C-terminal TFPI-2 sequences from 72 vertebrate organisms, using neighbor-joining method with 1000 bootstrap repeats, resulting in distinct groups (Fig. 1). The remainder of TFPI- 2 and full length protein are more conserved than the $\mathrm{C}$-terminal region, at first suggesting that the $\mathrm{C}$ terminal region has not been under evolutionary pressure

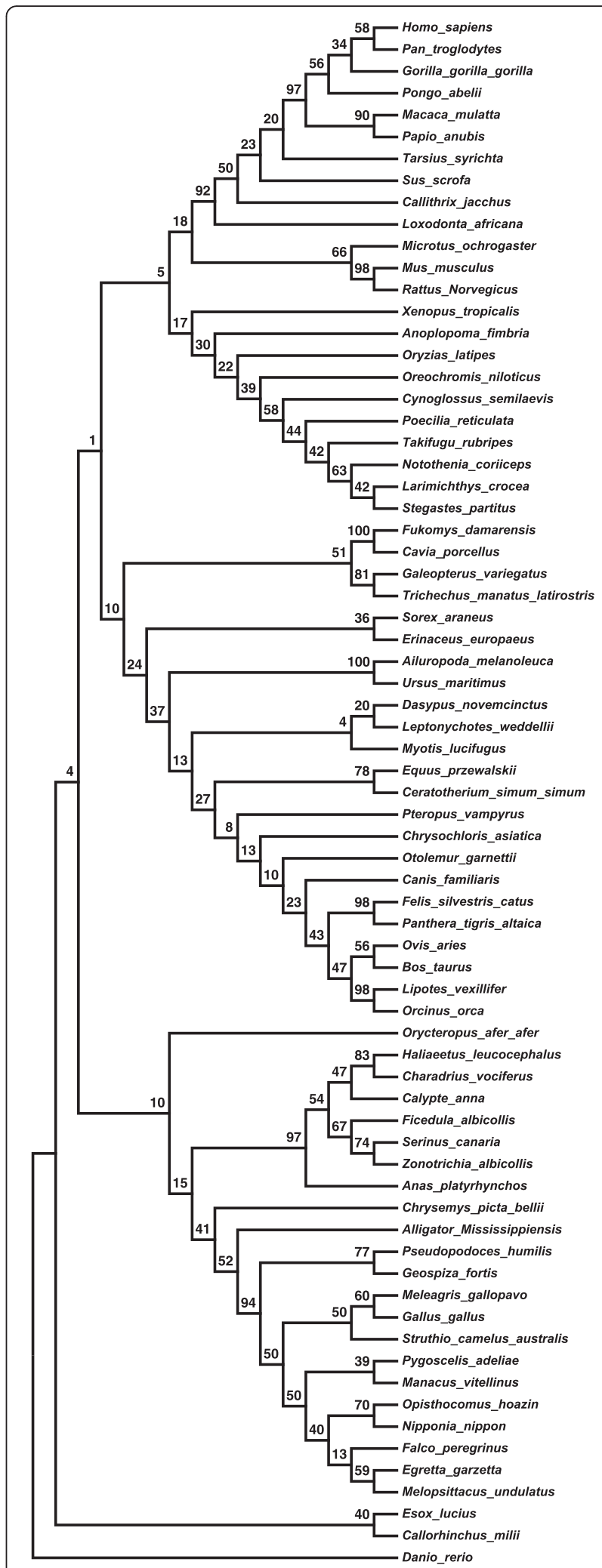

Fig. 1 Phylogenetic tree analysis of the C-terminal region of TFPI-2 from vertebrates. Phylogenetic tree from 72 vertebrate TFPI-2 species was constructed using Neighbour-Joining tree with 1000 bootstrap replications on MEGA6 
(Additional file 1: Figure S1). Even though the TFPI-2 amino acid length varies among the species, many other conserved regions were observed among the species (data not shown). Interestingly, the multiple sequence alignment of the C-terminal antimicrobial peptide region is not fully conserved (Fig. 2). Importantly however, even though the C-terminal region was not well conserved, the net positive charge is preserved, with a charge ranging from +7 to +14 (Table 1). This suggests an important role of the charge and points towards putative antimicrobial activity where charge rather than the exact amino acid sequence is essential.

\section{Antimicrobial activities of TFPI-2 C-terminal derived peptides}

Having identified the C-terminal region of TFPI-2, we next wished to investigate whether other vertebrate derived peptides retain similar bactericidal activity compared to the human peptide. The antimicrobial properties of the C-terminal TFPI-2 derived peptides from different vertebrates were assessed using radial diffusion assay against gram-negative bacteria E. coli and P. aeruginosa (Fig. 3). These species included primates (human and gorilla), rodents (mouse), birds (turkey and chicken), reptiles (alligator and turtle), amphibians (frog) and fishes (shark and zebra fish). We also noted that all vertebrate peptides displayed antimicrobial activities at concentrations of $100 \mu \mathrm{M}$ against both bacteria. In consensus with the human peptide, we investigated if also other vertebratederived peptides display enhanced bactericidal activity in presence of plasma. To this end, the peptides were incubated at varying concentrations with $E$. coli in presence of physiological buffer containing $20 \%$ human citrate plasma, since this $E$. coli strain is complement sensitive. In concordance with previous data, all vertebrate peptides displayed enhanced bactericidal activity against E. coli. Complete bacterial killing was observed at a concentration of $1 \mu \mathrm{M}$ in human plasma, which is due to boosting complement activation, whereas higher concentrations of the peptides were required for their direct antimicrobial activity as seen from incubating the peptide in presence of buffer (Fig. 4). The growth of bacteria in buffer is slower than in citrated plasma, but the peptide-mediated killing in buffer is still less efficient than in citrated plasma.

\section{Effect of TFPI-2 derived peptides on blood coagulation/ intrinsic pathway of coagulation}

Previously, it was shown that the human TFPI-2 derived peptide EDC34 blocks the intrinsic pathway of coagulation in both human and murine plasma [22]. Based on these findings we investigated the anticoagulant activity of the vertebrate-derived TFPI- 2 peptides by determining the prolongation of activated partial thromboplastin time (aPTT). As shown in Fig. 5a, all peptides effectively prolonged the normal clotting time on aPTT by more than $100 \mathrm{~s}$ when applied at a concentration of $50 \mu \mathrm{M}$. We further noted that all vertebrate-derived anticoagulant peptides tested are non-hemolytic at $60 \mu \mathrm{M}$ and thus have potential to be used in therapeutic applications (Fig. 5b).

\section{Mouse C-terminal TFPI-2 derived VKG24 peptide provides protection against septic shock}

Given the observed effects of the TFPI-2 C-terminal peptides, we made an attempt to find out whether these peptides are of therapeutic importance. To test whether the endogenous $\mathrm{C}$-terminal TFPI-2 region is important in host defense, the mouse peptide VKG24 was chosen for a murine in vivo model. In vitro, VKG24 peptide displayed potent antimicrobial and anti-coagulant activities in mouse plasma (Additional file 2: Figure S2). Thus, the in vivo efficiency of VKG24 peptide was evaluated in a standardized mouse model of endotoxin-induced shock [22]. A dramatic improvement in the survival rate of the animals was seen after treatment with the peptide ( $\sim 25 \mathrm{mg} / \mathrm{kg}$ body weight) (Fig. 6a). Peptide-treated animals started regaining their weight from day three (Fig. 6b). Previous studies have shown that thrombocytopenia is as an important indicator for the severity of sepsis and disseminated intravascular coagulation [23]. Therefore, activation of the intrinsic and extrinsic coagulation pathways was measured in citrate plasma of LPS-injected mice that received a VKG24 injection or were left untreated. The treatment showed significantly decreased coagulation aPTT and PT times in LPS challenged mice, indicating that the peptide reduced consumption of coagulation proteins (Fig. 6c). The levels were completely normalized in the survivors after seven days. Analyses of the cytokine profile $24 \mathrm{~h}$ after LPS injection showed significant reduction of IL-6, MCP-1, IFN- $\gamma$ and IL-10, respectively (Fig. 6d). Thus, the results demonstrate that the mouse VKG24 peptide exerts potent immunomodulatory activity.

\section{Discussion}

In the present study we aimed to study the host defence and immunomodulatory activities of the vertebrate Cterminal epitope of TFPI-2. Sequence analysis of this region in different vertebrate species showed that the exact amino acid sequence was not well conserved, whereas the net positive charge appeared to be preserved. These findings suggest an essential function of the charge. It can be speculated that there has been an evolutionary pressure to maintain the positive charge in the Cterminal region, as this is important in the host defence against bacterial pathogens. Within the last years, TFPI2 has attracted increasing attention because of its ubiquitous presence, which leads to the deposition in a 
Homo sapiens

Pan troglodytes

Callithrix jacchus

Macaca mulatta

Papio anubis

Pongo abelii

Gorilla gorilla gorilla

Tarsius syrichta

otolemur garnetti

Mus musculus

Microtus ochrogaster

Sorex araneus

Rattus Norvegicus

Fukomys damarensis

Cavia porcellusÂ

Erinaceus europaeus

Pteropus vampyrus

Myotis lucifugus

Chrysochloris asiatica

Galeopterus variegatus

Dasypus novemcinctus

Ovis aries

Felis silvestris catus

Loxodonta africana

Sus scrofa

Canis familiarisÂ

Ailuropoda melanoleuca

Bos taurusÂ

Ursus maritimus

Equus przewalskii

orycteropus afer afer

Panthera tigris altaica

Ceratotherium simum simum

Trichechus manatus latirostris

Leptonychotes weddellii

Lipotes vexillifer

Orcinus orca

Meleagris gallopavo

Pygoscelis adeliae

Haliaeetus leucocephalus

Falco peregrinus

Opisthocomus hoazin

Charadrius vociferus

Egretta garzetta

Struthio camelus australis

Nipponia nippon

Serinus canaria

Manacus vitellinus

Calypte anna

Pseudopodoces humilis

Melopsittacus undulatus

Ficedula albicollis

Anas platyrhynchos

Gallus gallus

Geospiza fortis

Zonotrichia albicollis

Esox lucius

Larimichthys crocea

Poecilia reticulata

Cynoglossus semilaevis

Stegastes partitus

Anoplopoma fimbriaÂ

Danio rerio

Oreochromis niloticus

Takifugu rubripes

Oryzias latipes

Notothenia coriiceps

Callorhinchus milii

Chrysemys picta bellii

Alligator Mississippiensis

Xenopus tropicalis

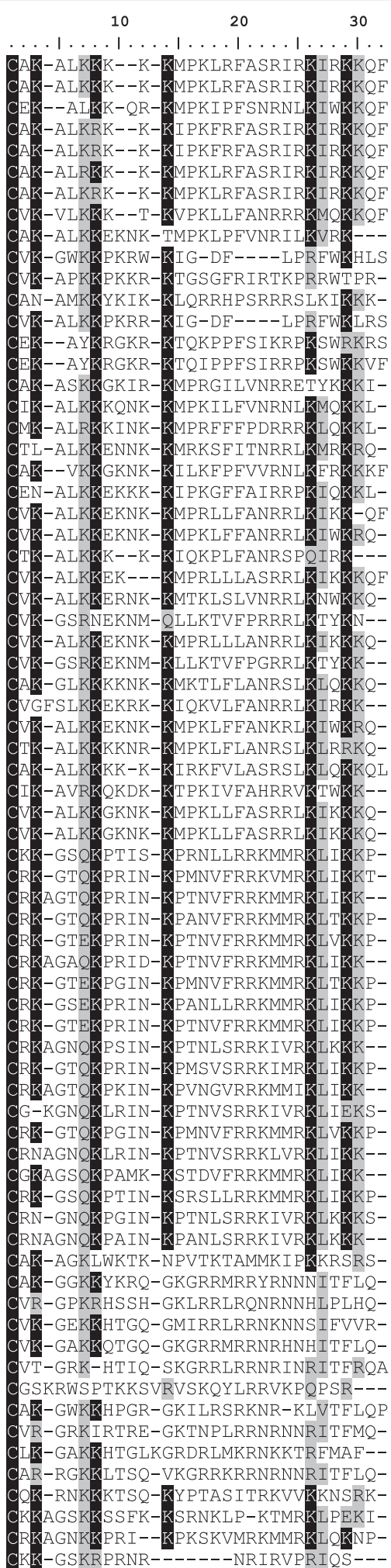

Fig. 2 Sequence homology of the C-terminal region of TFPI-2. ClustalW multiple sequence alignment of TFPI-2 where identical and similar amino acids in all sequences are highlighted in black and grey shaded, respectively 
Table 1 Multiple sequence alignment of vertebrate TFPI-2 C-terminal region showing identical and similar amino acids

\begin{tabular}{|c|c|c|c|c|}
\hline Entry \& name & Latin \& name & English \& name & Protein \& sequence & Net \& charge \\
\hline & & MAMMALS & & \\
\hline P48307 & Homo sapiens & Human & CAKALKKKKKMPKLRFASRIRKIRKKQF & 14 \\
\hline H2QUX8 & Pan troglodytes & Chimpanzee & CAKALKKKKKMPKLRFASRIRKIRKKQF & 14 \\
\hline U3ENJ1 & Callithrix jacchus & White-tufted-ear marmoset & CEKALKKQRKMPKIPFSNRNLKIWKKQF & 9 \\
\hline F7CWN2 & Macaca mulatta & Rhesus macaque & CAKALKRKKKIPKFRFASRIRKIRKKQF & 14 \\
\hline XP_003896360.1 & Papio anubis & Olive baboon & CAKALKRKKKIPKFRFASRIRKIRKKQF & 14 \\
\hline H2PMXO & Pongo abelii & Sumatran orangutan & CAKALRKKKKMPKLRFASRIRKIRKKQF & 14 \\
\hline G3QPC8 & Gorilla gorilla gorilla & Western lowland gorilla & CAKALKRKKKMPKLRFASRIRKIRKKQF & 14 \\
\hline XP_008067041.1 & Tarsius syrichta & Philippine tarsier & CVKVLKKKTKVPKLLFANRRRKMQKKQF & 12 \\
\hline HOXT57 & Otolemur garnettii & Small-eared galago & CAKALKKEKNKTMPKLPFVNRILKVRK & 9 \\
\hline O35536 & Mus musculus & Mouse & CVKGWKKPKRWKIGDFLPRFWKHLS & 7 \\
\hline XP_005363735.1 & Microtus ochrogaster & Prairie Vole & CVKAPKKPKKKRKTGSGFRIRTKPRRWTP & 12 \\
\hline XP_004602345.1 & Sorex araneus & European shrew & CANAMKKYKIKKLQRRHPSRRRSLKIKK & 13 \\
\hline EDL84392.1 & Rattus Norvegicus & Brown Rat & CVKALKKPKRRKIGDFLPRFWKLRS & 9 \\
\hline XP_010601797.1 & Fukomys damarensis & Damaraland Mole Rat & CEKAYKRGKRKTQKPPFSIKRPKSWRKR & 12 \\
\hline HOVU83 & Cavia porcellus & Guinea pig & CEKAYKRGKRKTQIPPFSIRRPKSWKKV & 10 \\
\hline XP_007522577.1 & Erinaceus europaeus & Western European Hedgehog & CAKASKKGKIRKMPRGILVNRRETYKKK & 11 \\
\hline XP_011361893.1 & Pteropus vampyrus & Large Flying Fox & CIKALKKKQNKKMPKILFVNRNLKMQKK & 11 \\
\hline G1PX03 & Myotis lucifugus & Little brown bat & CMKALRKKINKKMPRFFFPDRRRKLQKK & 12 \\
\hline XP_006834353.1 & Chrysochloris asiatica & Cape Golden Mole & CTLALKKENNKKMRKSFITNRRLKMRKR & 11 \\
\hline XP_008569808.1 & Galeopterus variegatus & Sunda flying lemur & CAKVKKGKNKKILKFPFWRNLKFRKKK & 13 \\
\hline XP_004475751.1 & Dasypus novemcinctus & Nine-banded Armadillo & CENALKKEKKKKIPKGFFAIRRPKIQKK & 10 \\
\hline W5NS10 & Ovis aries & Sheep & CVKALKKEKNKKMPRLLFANRRLKIKKQ & 11 \\
\hline M3X7K4 & Felis silvestris catus & Cat & CVKALKKEKNKKMPKLFFANRRLKIWKR & 11 \\
\hline G3THG9 & Loxodonta africana & African elephant & CTKALKKKKKIQKPLFANRSPQIRK & 10 \\
\hline F1SFC1 & Sus scrofa & Pig & CVKALKKEKKMPRLLLASRRLKIKKKQF & 11 \\
\hline E2RBFO & Canis familiaris & Dog & CVKALKKERNKKMTKLSLVNRRLKNWKK & 11 \\
\hline G1MHA9 & Ailuropoda melanoleuca & Giant panda & CVKGSRNEKNMQLLKTVFPRRRLKTYKN & 8 \\
\hline Q7YRQ8 & Bos taurus & Bovine & CVKALKKEKNKKMPRLLLANRRLKIKKK & 12 \\
\hline XP_008684473.1 & Ursus maritimus & Polar bear & CVKGSRKEKNMKLLKTVFPGRRLKTYKKK & 10 \\
\hline XP_008542988.1 & Equus przewalskii & Przewalski's horse & CAKGLKKKKNKKMKTLFLANRSLKLQKK & 12 \\
\hline XP_007938042.1 & Orycteropus afer afer & Aardvark & CVGFSLKKEKRKKIQKVLFANRRLKIRK & 11 \\
\hline XP_007076762.1 & Panthera tigris altaica & Amur Tiger & CVKALKKEKNKKMPKLFFANKRLKIWKR & 11 \\
\hline XP_004431409.1 & Ceratotherium simum simum & Southern White Rhinoceros & CTKALKKKKNRKMPKLLFLANRSLKLRRK & 13 \\
\hline XP_004386213.1 & Trichechus manatus latirostris & Florida manatee & CAKALKKKKKKIRKFVLASRSLKLQKKQ & 13 \\
\hline XP_006733001.1 & Leptonychotes weddellii & Weddell seal & CIKAVRKQKDKKTPKIVFAHRRVKTWKK & 11 \\
\hline XP_007450700.1 & Lipotes vexillifer & Yangtze River dolphin & CVKALKKGKNKKMPKLLFASRRLKIKKK & 13 \\
\hline \multirow[t]{2}{*}{ XP_004265641.1 } & Orcinus orca & Killer Whale & CVKALKKGKNKKMPKLLFASRRLKIKKK & 13 \\
\hline & & BIRDS & & \\
\hline XP_010710984 & Meleagris gallopavo & Wild Turkey & CKKGSQKPTISKPRNLLRRKMMRKLIKK & 12 \\
\hline XP_009328855.1 & Pygoscelis adeliae & Adélie penguin & CRKGTQKPRINKPMNVFRRKVMRKLIKK & 12 \\
\hline XP_010560815 & Haliaeetus leucocephalus & Bald eagle & CRKAGTQKPRINKPTNVFRRKMMRKLIK & 11 \\
\hline XP_005228880.1 & Falco peregrinus & Peregrine falcon & CRKGTQKPRINKPANVFRRKMMRKLTKK & 12 \\
\hline XP_009934468.1 & Opisthocomus hoazin & Hoatzin & CRKGTEKPRINKPTNVFRRKMMRKLVKK & 11 \\
\hline
\end{tabular}


Table 1 Multiple sequence alignment of vertebrate TFPI-2 C-terminal region showing identical and similar amino acids (Continued)

\begin{tabular}{|c|c|c|c|c|}
\hline XP_009893654.1 & Charadrius vociferus & Killdeer & CRKAGAQKPRIDKPTNVFRRKMMRKLIK & 10 \\
\hline XP_009639692.1 & Egretta garzetta & Little egret & CRKGTEKPGINKPMNVFRRKMMRKLTKK & 10 \\
\hline XP_009672625.1 & Struthio camelus australis & Ostrich & CRKGSEKPRINKPANLLRRKMMRKLIKK & 11 \\
\hline XP_009464906.1 & Nipponia nippon & Crested Ibis & CRKGTEKPRINKPTNVFRRKMMRKLIKK & 11 \\
\hline XP_009084577.1 & Serinus canaria & Atlantic canary & CRKAGNQKPSINKPTNLSRRKIVRKLKK & 11 \\
\hline XP_008919443.1 & Manacus vitellinus & Golden-collared manakin & CRKGTQKPRINKPMSVSRRKIMRKLIKK & 12 \\
\hline XP_008492487.1 & Calypte anna & Anna's hummingbird & CRKAGTQKPKINKPVNGVRRKMMIKLIK & 11 \\
\hline XP_005518860.1 & Pseudopodoces humilis & Ground tit & CGKGNQKLRINKPTNVSRRKIVRKLIEK & 9 \\
\hline XP_005152979.1 & Melopsittacus undulatus & Budgerigar & CRKGTQKPGINKPMNVFRRKMMRKLVKK & 11 \\
\hline XP_005041216.1 & Ficedula albicollis & The collared flycatcher & CRNAGNQKLRINKPTNVSRRKLVRKLIK & 10 \\
\hline XP_005010988.1 & Anas platyrhynchos & Mallard & CGKAGSQKPAMKKSTDVFRRKMMRKLIK & 9 \\
\hline$X P_{-} 418662.2$ & Gallus gallus & Chicken & CRKGSQKPTINKSRSLLRRKMMRKLIKK & 12 \\
\hline XP_005418689.1 & Geospiza fortis & Medium ground finch & CRNGNQKPGINKPTNLSRRKIVRKLKKK & 11 \\
\hline \multirow[t]{2}{*}{ XP_005480303.1 } & Zonotrichia albicollis & White-throated Sparrow & CRNAGNQKPAINKPANLSRRKIVRKLKK & 10 \\
\hline & & REPTILES & & \\
\hline XP_005308608.1 & Chrysemys picta bellii & Western painted turtle & CKKAGSKKSSFKKSRNKLPKTMRKLPEK & 11 \\
\hline \multirow[t]{2}{*}{ XP_006258519.1 } & Alligator Mississippiensis & American Alligator & CRKAGNKKPRIKPKSKVMRKMMRKLQKN & 13 \\
\hline & & AMPHIBIANS & & \\
\hline \multirow[t]{2}{*}{ Q5FVY6 } & Xenopus tropicalis & Western clawed frog & CKKGSKRPRNRNRIRVPRIQS & 9 \\
\hline & & FISHES & & \\
\hline XP_010889816.1 & Esox lucius & The northern pike & CAKAGKLWKTKNPVTKTAMMKIPKKRSR & 10 \\
\hline XP_010739844.1 & Larimichthys crocea & Croceine croaker & CAKGGKKYKRQGKGRRMRRYRNNNITFL & 11 \\
\hline XP_008419957.1 & Poecilia reticulata & Guppy & CVRGPKRHSSHGKLRRLRQNRNNHLPLH & 8 \\
\hline XP_008329541.1 & Cynoglossus semilaevis & Cynoglossus & CVKGEKKHTGQGMIRRLRRNKNNSIFW & 7 \\
\hline XP_008287494.1 & Stegastes partitus & Bicolor damselfish & CVKGAKKQTGQGKGRRMRRNRHNHITFL & 9 \\
\hline XP_007259866.1 & Mexican tetra & Astyanax mexicanus & CARKSKPGKMRRKLIPRKPERRI & 10 \\
\hline $\mathrm{C} 3 \mathrm{KHI} 5$ & Anoplopoma fimbria & Sablefish & CVTGRKHTIQSKGRRLRRNRINRITFRQ & 10 \\
\hline Q1WCN6 & Danio rerio & Zebrafish & CGSKRWSPTKKSVRVSKQYLRRVKPQPS & 9 \\
\hline $13 \mathrm{JXJ8}$ & Oreochromis niloticus & Nile tilapia & CAKGWKKHPGRGKILRSRKNRKLVTFLQ & 10 \\
\hline XP_003969359.1 & Takifugu rubripes & Japanese Puffer & CVRGRKIRTREGKTNPLRRNRNNRITFM & 9 \\
\hline XP_004073873.1 & Oryzias latipes & Japanese Rice Fish & CLKGAKKHTGLKGRDRLMKRNKKTRFMA & 10 \\
\hline XP_010772945.1 & Notothenia coriiceps & Black Rock Cod & CARRGKKLTSQVKGRRKRRNRNNRITFL & 12 \\
\hline XP_007903512.1 & Callorhinchus milii & Australian Ghostshark & CQKRNKKKTSQKYPTASITRKWKKNSR & 11 \\
\hline
\end{tabular}

variety of tissues and particularly in the extracellular matrix. This likely reflects its potential as a central regulator of multiple biological processes involving the control of inflammatory reactions, matrix protease activity, coagulation, angiogenesis, and tumour growth. In previous studies we found that the proteolysis of human TFPI-2 generates C-terminal fragments, both in vivo and in vitro after digestion with neutrophil elastase. These findings are of importance in the context of proteolysis of TFPI-2 and possible release of bioactive host defence fragments $[9,10]$. Notably, the observed generation of C-terminal fragments of TFPI-2 are very similar to that seen with TFPI-1, suggesting that the same cleavage sites is used by plasmin and thrombin to generate the C-terminal part of TFPI-1. Interestingly, previous data on TFPI- 1 and TFPI- 2 revealed that the release of C-terminal peptides may exert similar complement boosting effects [8-10]. It is also notable that the Cterminal peptide of TFPI-1, GGL27, and TFPI-2, EDC34 prolongs aPTT, thus further illustrating a functional overlap between the two TFPI proteins. In a broader perspective, a picture thus emerges; suggesting that $\mathrm{C}$ terminal fragments from both TFPI-1 and TFPI- 2 may be released during inflammation and infection, serving as modulators of both antimicrobial activity and coagulation. So far, available structural and functional data 


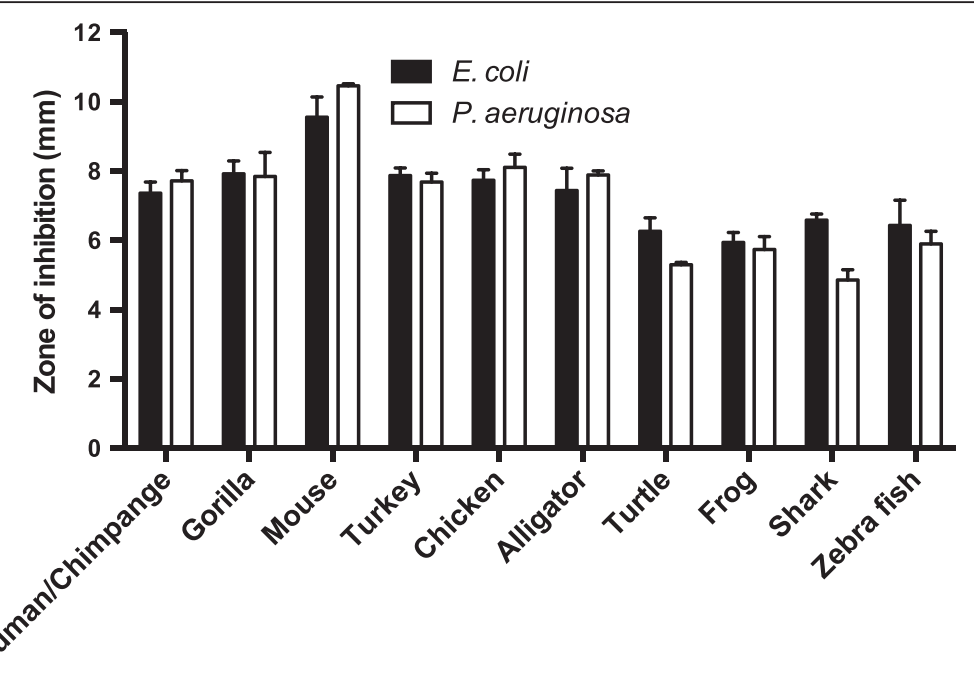

Fig. 3 Antimicrobial activities of TFPI-2 C-terminal derived peptides from different species. For determination of antimicrobial activities, E. coli ATCC 25922 and P. aeruginosa ATCC $27853\left(4 \times 10^{6} \mathrm{cfu}\right)$ were inoculated in $0.1 \%$ TSB agarose gel. Each $4 \mathrm{~mm}$-diameter well was loaded with $6 \mu$ l of peptide (at $100 \mu \mathrm{M}$ ). The zones of clearance (in $\mathrm{mm}$ ) correspond to the inhibitory effect of each peptide after incubation at $37^{\circ} \mathrm{C}$ for $18-24 \mathrm{~h}$ (mean values are presented, $n=3$ ). A control with buffer only yielded no inhibition zone

separate the C-terminal TFPI-2 peptides from the group of classical amphipathic antimicrobial peptides, such as the helical cathelicidin peptide LL-37 as well as defensins. Indeed, the EDC34 show a similarity to some linear peptides of low helical content, such as antimicrobial peptides derived from growth factors [24] as well as human kininogen, all displaying mostly random coil conformation in buffer and at lipid bilayers, the interactions dominated by electrostatic interactions [25].

It remains to be investigated whether TFPI- 2 peptides may have similar actions as those reported here, although the absence of a marked boosting of activity in plasma suggests that complement interactions are characteristic for the TFPI-peptides. The detailed mode of action of these peptides remains to be explored, but it seems that they are involved in interactions with $\mathrm{C} 1 \mathrm{q}$ and/or other molecules that can initiate the classical pathway of complement and lead to the formation of C3a or a MAC complex. Contact activation, involving degradation of human kininogen, and release of vasoactive bradykinin has been reported during various infective processes including sepsis $[26,27]$. The finding that EDC34 inhibited contact activation in vitro is of importance, since a generalized activation of the system can be deleterious.

From a clinical perspective, many opportunistic bacteria can cause both localized and systemic infections and are responsible for considerable mortality or morbidity in patients suffering from burn wound infections, pneumonia, cystic fibrosis, intra-abdominal infections, chronic ulcers, and sepsis. Our results show a direct antimicrobial activity of the TFPI-2 peptide derived from different vertebrates species. The potent antimicrobial activity of these peptides was paired with boosting of complement activation and a modulation of the coagulation cascade. In vivo, VKG24 administration after LPS challenge protects mice and also significantly reduced aPTT and PT time. Therefore, our findings that VKG24 is able to significantly reduce LPS induced shock is particularly relevant, and implies a therapeutic potential for VKG24. The protective effect of mouse VKG24 in infections caused by Gram-negative pathogens may also apply to other vertebrate TFPI-2 Cterminal peptides.

\section{Conclusions}

Several therapeutic strategies to combat severe infections including sepsis are based on supplementation of antibiotics with molecules exerting anti-coagulant and anti-inflammatory actions [28]. The dual effects of these natural peptides, for example the mouse derived VKG24 peptide, that can block contact activation and boost complement activation, thus represent, to our knowledge, a novel treatment concept, which could enable complement mediated bacterial clearance while inhibiting the deleterious effects of excessive procoagulant responses during infection with Gramnegative bacteria.

\section{Methods}

Peptides

Indicated peptides (Additional file 3: Table S1) were synthesized by Ontores (Shanghai, China). The purity (>98 \%) 

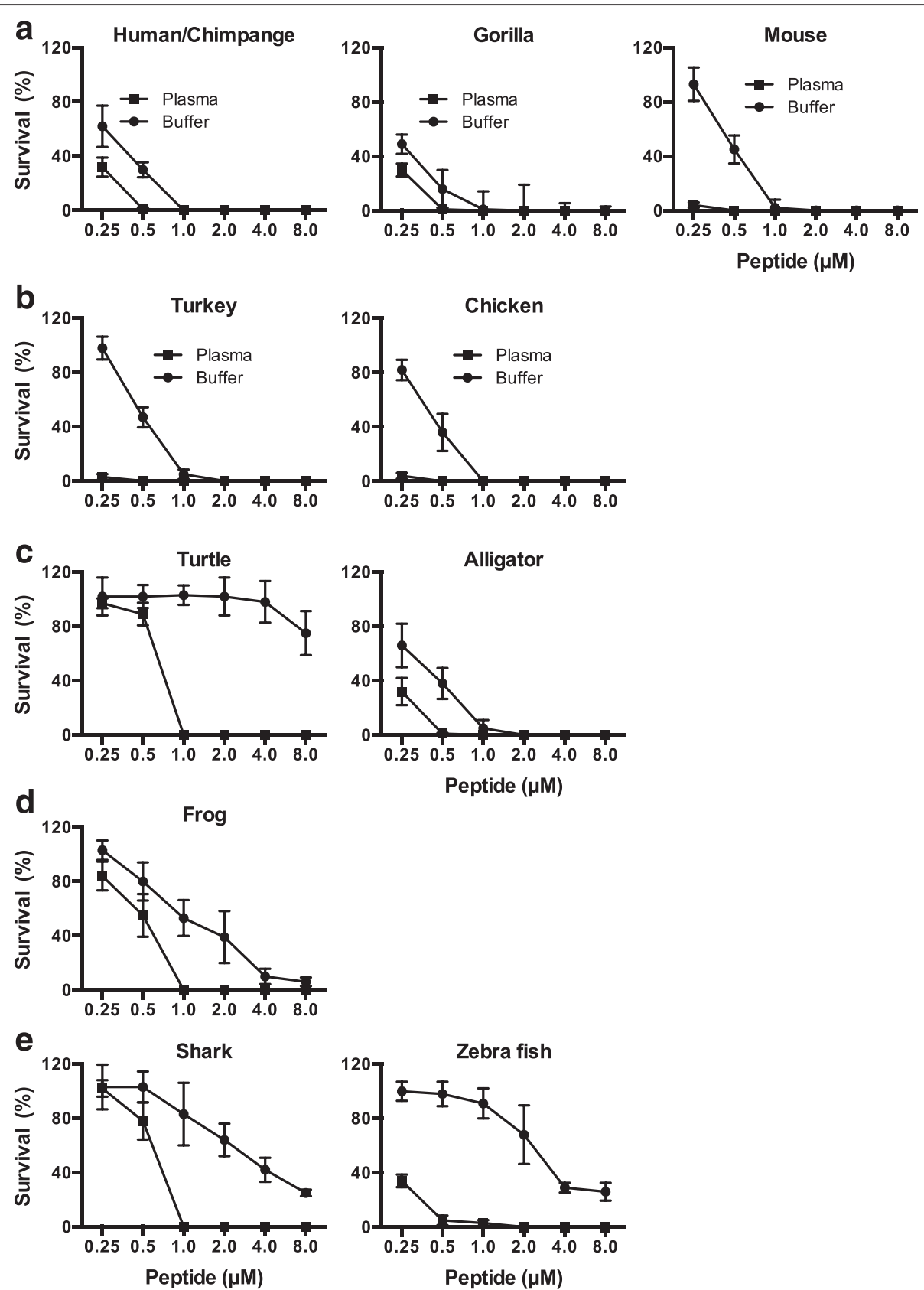

Fig. 4 Activities of TFPI-2 C-terminal derived peptides in human plasma. The bactericidal activity of TFPI-2 peptides was assessed in physiological buffer conditions using viable count analysis. a-e Bacteria E. coli ATCC 25922 were grown to mid-logarithmic phase and incubated with varying concentrations of peptides corresponding to sequences found in mammals, birds, reptiles, frog and fish species. Peptides were used in buffer containing $0.15 \mathrm{M} \mathrm{NaCl}, 10 \mathrm{mM}$ Tris, pH 7.4 alone, or in presence of $20 \%$ human plasma. The antimicrobial activity was determined by plating serial dilution of bacteria on TH agar plates and number of cfu was counted after overnight incubation. All investigated peptides showed dose dependent bactericidal activity and $100 \%$ bacterial killing was achieved in all cases at $1 \mu \mathrm{M}$ concentration

of these peptides was confirmed by mass spectral analysis (MALDI-ToF Voyager).

\section{Microorganisms}

The bacterial isolates E. coli ATCC 25922 and P. aeruginosa ATCC 27853 were obtained from the American Type Culture Collection.

\section{Radial diffusion assay (RDA)}

Essentially as described earlier, bacteria were grown to mid-logarithmic phase in $10 \mathrm{ml}$ of full-strength $(3 \% \mathrm{w} / \mathrm{v})$ trypticase soy broth (TSB) (Becton-Dickinson, Cockeysville, MD). The microorganisms were then washed once with $10 \mathrm{mM}$ Tris, $\mathrm{pH}$ 7.4. Subsequently, $4 \times 10^{6}$ bacterial colony forming units (cfu) were added to $15 \mathrm{ml}$ of the underlay 


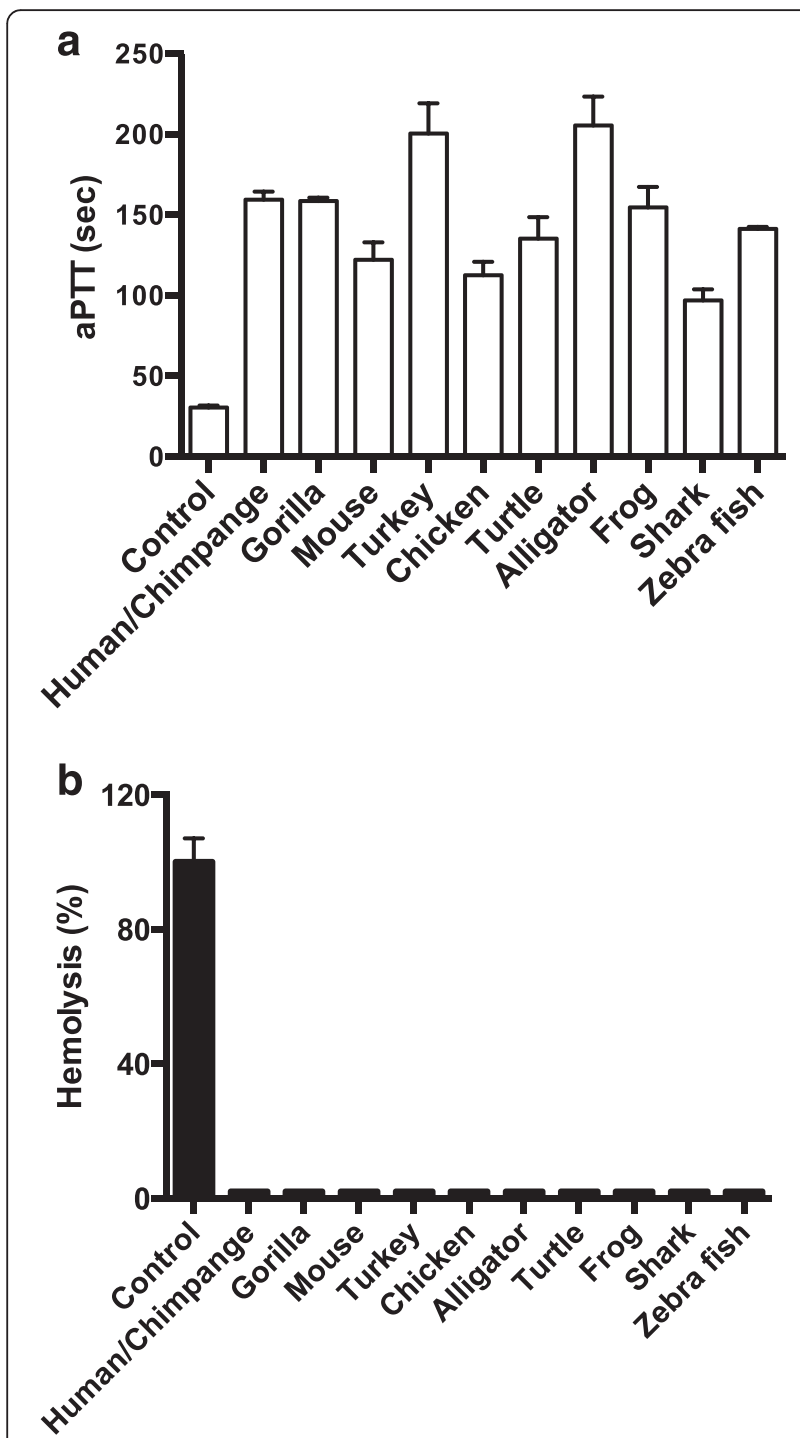

Fig. 5 Anticoagulant effects of TFPI-2 derived peptides. a The activated partial thromboplastin time (aPTT) was determined by addition of buffer or $50 \mu \mathrm{M}$ of different vertebrate TFPI-2 derived peptides to human plasma. Data are presented as clotting time in seconds; values are mean \pm SD $(n=3)$. $\mathbf{b}$ Human erythrocytes were incubated with $60 \mu \mathrm{M}$ of vertebrate TFPI-2 derived peptides. The hemoglobin release was measured at $\lambda 540 \mathrm{~nm}$ and hemolysis was indicated in percentage, Triton $\mathrm{X}-100$ treated sample being used a positive control

agarose gel, consisting of $0.03 \%(\mathrm{w} / \mathrm{v})$ TSB, $1 \%(\mathrm{w} / \mathrm{v})$ low electroendosmosis type (EEO) agarose (Sigma, St Louis, MO) and $0.02 \%(\mathrm{v} / \mathrm{v})$ Tween 20 (Sigma). The underlay was poured into a $\varnothing 144 \mathrm{~mm}$ petri dish. After agarose solidification, $4 \mathrm{~mm}$-diameter wells were punched and $6 \mu \mathrm{l}$ of test sample was added to each well. Plates were incubated at $37{ }^{\circ} \mathrm{C}$ for $3 \mathrm{~h}$ to allow diffusion of the peptides. The underlay gel was then covered with $15 \mathrm{ml}$ of molten overlay (6\% TSB and $1 \%$ Low-EEO agarose in distilled $\mathrm{H}_{2} \mathrm{O}$ ). Antimicrobial activity of a peptide is visualized as a zone of clearing around each well after $18-24 \mathrm{~h}$ of incubation at $37{ }^{\circ} \mathrm{C}$.

\section{Viable count analysis (VCA)}

E. coli were grown to mid-exponential phase in ToddHewitt (TH). Bacteria were washed and diluted in $10 \mathrm{mM}$ Tris, pH 7.4 either alone or with $20 \%$ human or mouse $(B A L B / c)$ citrate-plasma. Bacterial $\left(2 \times 10^{6} \mathrm{cfu} / \mathrm{ml}\right)$ were incubated in $50 \mu \mathrm{l}$, at $37{ }^{\circ} \mathrm{C}$ for $1 \mathrm{~h}$ with the $\mathrm{C}$ terminal TFPI- 2 derived peptides at the indicated concentrations. Serial dilutions of the incubation mixture were plated on $\mathrm{TH}$ agar, followed by incubation at $37{ }^{\circ} \mathrm{C}$ overnight and cfu determination.

\section{LPS animal model}

Male/female balb/c mice ( 8 weeks, $21 \pm 5 \mathrm{~g}$ ) were injected intraperitoneally (i.p.) with $10 \mathrm{mg}$ E. coli 0111:B4 LPS (Sigma) per $\mathrm{kg}$ of body weight. Thirty minutes after LPS injection, $0.5 \mathrm{mg}$ VKG24 $(25 \mathrm{mg} / \mathrm{kg})$ or PBS buffer alone (control) were injected i.p. into the mice. Status and weight were monitored daily for seven days. Mice where immobilization and/or shaking was observed were euthanized by an overdose of isoflurane (Abbott) and counted as non-survivors. For determination of cytokine levels in mouse plasma, animals were sacrificed $24 \mathrm{~h}$ after LPS injection. The blood was collected immediately by cardiac puncture into citrate tubes.

\section{Cytokine assay}

Cytokines IL-6, IL-10, MCP-1, INF- $\gamma$ and TNF- $\alpha$ were measured in plasma from mice infected by $E$. coli LPS (with or without peptide treatment) using the Cytometric bead array; mouse inflammation kit (Becton Dickinson $\mathrm{AB}$ ) according to the manufacturer's instructions. All plasma samples were stored at $-80{ }^{\circ} \mathrm{C}$ before the analysis.

\section{Hemolysis assay}

EDTA-blood was centrifuged at $800 \times g$ for $10 \mathrm{~min}$, where after plasma and buffy coat were removed. The erythrocytes were washed three times and resuspended in PBS, pH 7.4 to get a $5 \%$ suspension. The cells were then incubated with end-over-end rotation for $60 \mathrm{~min}$ at $37{ }^{\circ} \mathrm{C}$ in the presence of peptides $(60 \mu \mathrm{M})$. Triton $\mathrm{X}-100$ (Sigma) $2 \%$ served as positive control. The samples were then centrifuged at $800 \times g$ for $10 \mathrm{~min}$ and the supernatant was transferred to a 96 well microtiter plate. The absorbance of hemoglobin release was measured at $540 \mathrm{~nm}$ and expressed as percentage of Triton X-100 induced hemolysis.

\section{Phylogenetic and sequence homology analyses}

Various vertebrate TFPI- 2 amino acid sequences, which are presently available, were retrieved from the NCBI, 

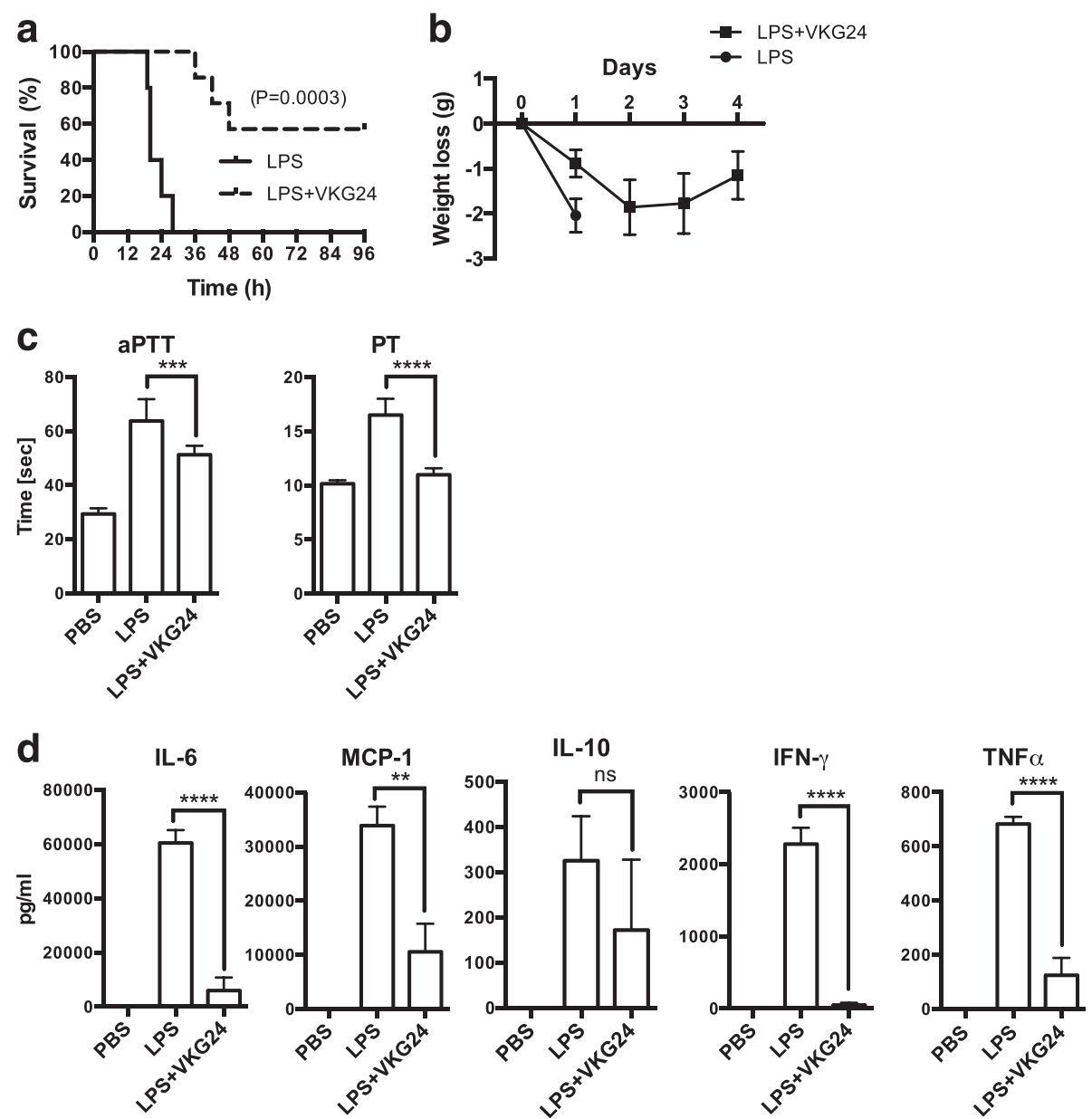

Fig. 6 Treatment of LPS-induced septic shock mice with a mouse TFPI-2 derived peptide. Septic shock in Balb/c mice was induced by i.p. injection of $10 \mathrm{mg} / \mathrm{kg}$ E. coli LPS. Thirty minutes after LPS injection, VKG24 (0.5 mg/mouse or $\sim 25 \mathrm{mg} / \mathrm{kg}$ body weight) or PBS was administrated i.p. a Mouse TFPI-2 derived peptide significantly increased survival of mice. Survival of mice was monitored for 7 days (only the first $96 \mathrm{~h}$ is shown in the figure). Statistical comparisons of survival curves were performed using the Mantel-Cox's test. ${ }^{* * *} \leq \leq 0.0003$. b Weight was determined daily. c Clotting times of aPTT and PT was measured in citrate plasma $24 \mathrm{~h}$ after LPS injection $(n=8)$. $\mathbf{d}$ The indicated cytokines were analyzed in plasma $24 \mathrm{~h}$ after LPS injection $(n=8)$. Statistical analysis for C-D, one-way ANOVA with Tukey's multiple comparisons post-test was used. ${ }^{*} P \leq 0.003,{ }^{* * *} P \leq 0.0001$

Ensembl and Uniprot. These sequences were aligned using Blosum 69 protein weight matrix settings using BioEdit software (Ibis Biosciences, Carlsbad, CA). Internal adjustments were made taking the structural alignment into account utilizing the ClustalW interface. Neighbor-joining method was used for phylogenetic tree construction, and the reliability of each branch was assessed using 1000 bootstrap replications using Mega-6.

\section{Clotting assays}

All clotting times were analyzed using a coagulometer (Amelung, Lemgo, Germany). For determination of activated partial thromboplastin time (aPTT), $100 \mu \mathrm{l}$ of a kaolin-containing solution (Technoclone) was added to the $100 \mu \mathrm{l}$ of fresh citrate plasma or citrate plasma peptide mix and incubated at $37{ }^{\circ} \mathrm{C}$ for $200 \mathrm{~s}$ before clot formation was initiated by adding $100 \mu \mathrm{l}$ of $30 \mathrm{mM}$ fresh $\mathrm{CaCl}_{2}$ solution. For detection of prothrombin time (PT, thromboplastin reagent (Trinity Biotech)) $100 \mu \mathrm{l}$ of fresh citrate plasma were incubated $60 \mathrm{~s}$ at $37^{\circ} \mathrm{C}$ before clot formation was initiated by adding $100 \mu \mathrm{l}$ of clotting reagent.

\section{Statistical analysis}

Values are shown as mean with SEM. For statistical evaluation of two experimental groups, one-way with Tukey's multiple comparisons post-test was used and for comparison of survival curves the Mantel-Cox's test. Viable count and radial diffusion assay data are presented as mean with SD. All statistical evaluations were performed using the GraphPad Prism software 6.0 with ${ }^{*} p-<0.05,{ }^{* * *} p-<0.01,{ }^{* * * *}<0.001,{ }^{* * * * * *} p<0.0001$ and $\mathrm{ns}=$ not significant. 


\section{Additional files}

Additional file 1: Figure S1. Phylogenetic tree analysis of full-length and reminder protein except C-terminal TFPI-2 from vertebrates. Phylogenetic tree from 72 vertebrate TFPI-2 species was constructed using NeighbourJoining tree with 1000 bootstrap replications on MEGA6. (PDF 54 kb)

Additional file 2: Figure S2. Activities of TFPI-2 C-terminal derived peptides in mouse plasma. (Left) The bactericidal activity of mouse VKG24 peptide was assessed in physiological buffer conditions using viable count analysis. E. coli ATCC 25922 were grown to mid-logarithmic phase and incubated with varying concentrations of peptide. The antimicrobial activity was determined by plating serial dilutions of bacteria on $\mathrm{TH}$ agar plates and number of cfu was counted after overnight incubation. (Right) The activated partial thromboplastin time (aPTT) was determined by addition of buffer or $50 \mu \mathrm{M}$ of VKG24 peptide to mouse plasma. Data are presented as clotting time in seconds; values are mean \pm SD $(n=3)$. (PDF $32 \mathrm{~kb})$

Additional file 3: Table S1. Selected vertebrate TFPI-2 C-terminal peptides showing sequence entry name, species, sequence, charge and hydrophobicity. (PDF $73 \mathrm{~kb})$

\section{Abbreviations}

aPTT, activated partial thromboplastin time; PT, prothrombin time; TFPI-2, tissue factor pathway inhibitor-2

\section{Acknowledgements}

We wish to thank Professors Heiko Herwald, Artur Schmidtchen and Arne Egesten for their support.

\section{Funding}

This work was supported by grants from the Crafoord (http://www.crafoord.se) and The Royal Physiographic Society in Lund (http://www.fysiografen.se/sv/).

\section{Availability of data and materials}

The data sets supporting the results of this article are included within the article. For phylogenetic analysis, vertebrate species protein accession numbers are available in Table 1.

\section{Authors' contributions}

PP designed the experiments. GK, ES, EM, LW, SA and PP performed the experiments. PP analyzed the data and wrote the paper. All authors read and approved the final manuscript.

\section{Competing interests}

The authors declare that they have no competing interests.

\section{Consent for publication}

Not applicable.

\section{Ethics approval and consent to participate}

Animals were housed under standard conditions of light and temperature and had free access to standard laboratory chow and water. Animal use protocols (M185-14) were approved by the Animal Ethics Committee of Malmö/Lund.

\section{Author details}

${ }^{1}$ Division of Respiratory Medicine and Allergology, Lund University, Lund, Sweden. ${ }^{2}$ Division of Infection Medicine, Department of Clinical Sciences, Lund University, Biomedical Center, B14, Tornavägen 10, SE-221 84 Lund, Sweden. ${ }^{3}$ School of Biosciences and Technology, Environmental Division, VIT University, Tamil Nadu, India. ${ }^{4}$ Dept of Biotechnology, DKM college for Women, Sainathapuram, 632001 Vellore, India.

Received: 8 January 2016 Accepted: 15 June 2016 Published online: 27 June 2016

\section{References}

1. Krem MM, Di Cera E. Evolution of enzyme cascades from embryonic development to blood coagulation. Trends Biochem Sci. 2002;27(2):67-74.
2. Papareddy P, Rydengård V, Pasupuleti M, Walse B, Mörgelin M, Chalupka A, Malmsten M, Schmidtchen A Proteolysis of human thrombin generates novel host defense peptides. PLoS Pathog. 2010;6(4), e1000857.

3. Frick IM, Åkesson P, Herwald H, Mörgelin M, Malmsten M, Nagler DK, Björck $\mathrm{L}$. The contact system-a novel branch of innate immunity generating antibacterial peptides. Embo J. 2006;25(23):5569-78.

4. Malmström E, Mörgelin M, Malmsten M, Johansson L, Norrby-Teglund A, Shannon O, Schmidtchen A, Meijers JC, Herwald H. Protein C inhibitor-a novel antimicrobial agent. PLoS Pathog. 2009;5(12), e1000698.

5. Tang YQ, Yeaman MR, Selsted ME. Antimicrobial peptides from human platelets. Infect Immun. 2002;70(12):6524-33.

6. Riedel T, Suttnar J, Brynda E, Houska M, Medved L, Dyr JE. Fibrinopeptides $A$ and $B$ release in the process of surface fibrin formation. Blood. 2011; 117(5):1700-6.

7. Papareddy $\mathrm{P}$, Kalle M, Bhongir RK, Mörgelin M, Malmsten M, Schmidtchen A Antimicrobial effects of helix D-derived peptides of human antithrombin III. J Biol Chem. 2014;289(43):29790-800.

8. Papareddy $P$, Kalle $M$, Kasetty $G$, Mörgelin M, Rydengård V, Albiger B, Lundqvist K, Malmsten M, Schmidtchen A. C-terminal peptides of tissue factor pathway inhibitor are novel host defense molecules. J Biol Chem. 2010:285(36):28387-98.

9. Papareddy P, Kalle M, Sorensen OE, Lundqvist K, Mörgelin M, Malmsten M, Schmidtchen A. Tissue factor pathway inhibitor 2 is found in skin and its Cterminal region encodes for antibacterial activity. PLoS One. 2012;7(12), e52772

10. Papareddy $P$, Kalle $M$, Sorensen OE, Malmsten M, Mörgelin M, Schmidtchen A. The TFPI-2 derived peptide EDC34 improves outcome of gram-negative sepsis. PLoS Pathog. 2013;9(12), e1003803.

11. Hilchie AL, Wuerth $\mathrm{K}$, Hancock RE. Immune modulation by multifaceted cationic host defense (antimicrobial) peptides. Nat Chem Biol. 2013; 9(12):761-8.

12. Choi KY, Chow LN, Mookherjee N. Cationic host defence peptides: multifaceted role in immune modulation and inflammation. J Innate Immun. 2012;4(4):361-70.

13. Hancock RE, Nijnik A, Philpott DJ. Modulating immunity as a therapy for bacterial infections. Nat Rev Microbiol. 2012;10(4):243-54.

14. Chand HS, Foster DC, Kisiel W. Structure, function and biology of tissue factor pathway inhibitor-2. Thromb Haemost. 2005;94(6):1122-30.

15. Sprecher CA, Kisiel W, Mathewes S, Foster DC. Molecular cloning, expression, and partial characterization of a second human tissue-factor-pathway inhibitor. Proc Natl Acad Sci U S A. 1994;91(8):3353-7.

16. Udagawa K, Miyagi $Y$, Hirahara F, Miyagi E, Nagashima $Y$, Minaguchi $H$, Misugi K, Yasumitsu H, Miyazaki K. Specific expression of PP5/TFPI2 mRNA by syncytiotrophoblasts in human placenta as revealed by in situ hybridization. Placenta. 1998:19(2-3):217-23.

17. lino M, Foster DC, Kisiel W. Quantification and characterization of human endothelial cell-derived tissue factor pathway inhibitor-2. Arterioscler Thromb Vasc Biol. 1998;18(1):40-6.

18. Petersen LC, Sprecher CA, Foster DC, Blumberg H, Hamamoto T, Kisiel W. Inhibitory properties of a novel human Kunitz-type protease inhibitor homologous to tissue factor pathway inhibitor. Biochemistry. 1996;35(1): 266-72.

19. Kong D, Ma D, Bai H, Guo H, Cai X, Mo W, Tang Q, Song H. Expression and characterization of the first kunitz domain of human tissue factor pathway inhibitor-2. Biochem Biophys Res Commun. 2004;324(4):1179-85.

20. Hisaka T, Lardeux B, Lamireau T, Wuestefeld T, Lalor PF, Neaud V, Maurel P, Desmouliere A, Kisiel W, Trautwein C et al. Expression of tissue factor pathway inhibitor-2 in murine and human liver regulation during inflammation. Thromb Haemost. 2004;91(3):569-75.

21. Torres-Collado AX, Kisiel W, Iruela-Arispe ML, Rodriguez-Manzaneque JC. ADAMTS1 interacts with, cleaves, and modifies the extracellular location of the matrix inhibitor tissue factor pathway inhibitor-2. J Biol Chem. 2006; 281(26):17827-37.

22. Kalle M, Papareddy P, Kasetty G, Mörgelin M, van der Plas MJ, Rydengård V, Malmsten M, Albiger B, Schmidtchen A. Host defense peptides of thrombin modulate inflammation and coagulation in endotoxin-mediated shock and Pseudomonas aeruginosa sepsis. PLoS One. 2012;7(12), e51313.

23. Levi M, Schultz M, van der Poll T. Sepsis and thrombosis. Semin Thromb Hemost. 2013:39(5):559-66.

24. Malmsten $M$, Davoudi $M$, Walse $B$, Rydengård V, Pasupuleti $M$, Mörgelin $M$, Schmidtchen A. Antimicrobial peptides derived from growth factors. Growth Factors. 2007;25(1):60-70 
25. Ringstad L, Andersson Nordahl E, Schmidtchen A, Malmsten M. Composition effect on peptide interaction with lipids and bacteria: variants of C3a peptide CNY21. Biophys J. 2007:92(1):87-98.

26. Persson K, Mörgelin M, Lindbom L, Alm P, Björck L, Herwald H. Severe lung lesions caused by Salmonella are prevented by inhibition of the contact system. J Exp Med. 2000;192(10):1415-24.

27. Pixley RA, DeLa Cadena RA, Page JD, Kaufman N, Wyshock EG, Colman RW, Chang A, Taylor FB, Jr.. Activation of the contact system in lethal hypotensive bacteremia in a baboon model. Am J Pathol. 1992;140(4):897-906.

28. de Jong HK, van der Poll T, Wiersinga WJ. The systemic pro-inflammatory response in sepsis. J Innate Immun. 2010;2(5):422-30.

Submit your next manuscript to BioMed Central and we will help you at every step:

- We accept pre-submission inquiries

- Our selector tool helps you to find the most relevant journal

- We provide round the clock customer support

- Convenient online submission

- Thorough peer review

- Inclusion in PubMed and all major indexing services

- Maximum visibility for your research

Submit your manuscript at www.biomedcentral.com/submit
Biomed Central 